\title{
Declining prevalence of hepatitis A virus antibodies among children from low socioeconomic groups reinforces the need for the implementation of hepatitis A vaccination in Brazil
}

\author{
Claudia Lamarca Vitrall ${ }^{1,2} /{ }^{+}$, Fidel Leonardo Navarro Ospina ${ }^{3}$, Solange Artimos ${ }^{3}$, \\ Juliana Gil Melgaço ${ }^{2,3}$, Oswaldo Gonçalves $\mathrm{Cruz}^{4}$, Vanessa Salete de Paula ${ }^{2}$, \\ Sérgio Bessa Luz ${ }^{5}$, Marcos Freire ${ }^{6}$, Luciane Pinto Gasparr, Luciane Almeida Amado², \\ Elyne Montenegro Engstrom 7 , Camila Dufrayer Fanzeres Monteiro Fortes ${ }^{8}$, Tayla Coleta de Souza ${ }^{8}$, \\ Marisa Nishitani Dias ${ }^{9}$, Ana Maria Coimbra Gaspar², Francisco José Dutra Souto ${ }^{8}$

\footnotetext{
'Departamento de Microbiologia e Parasitologia, Instituto Biomédico 3Pós-graduação em Ciências Médicas, Universidade Federal Fluminense, Niterói, RJ, Brasil ${ }^{2}$ Laboratório de Desenvolvimento Tecnológico em Virologia Germano Sinval Faria, Escola Nacional de Saúde Pública, Instituto Oswaldo Cruz-Fiocruz, Rio de Janeiro, RJ, Brasil ${ }^{5}$ Centro de Pesquisa Leônidas \& Maria Deane-Fiocruz, Manaus, AM, Brasil ${ }^{8}$ Faculdade de Medicina, Universidade Federal de Mato Grosso, Cuiabá, MT, Brasil ${ }^{9}$ Secretaria de Saúde do Município, Cuiabá, MT, Brasil
} \\ ${ }^{4}$ Programa de Computação Científica ${ }^{6}$ Laboratório de Tecnologia Virológica, Bio-Manguinhos ${ }^{7}$ Centro de Saúde Escola
}

Age-related seroprevalence studies that have been conducted in Brazil have indicated a transition from a high to a medium endemicity of hepatitis A virus (HAV) infection in the population. However, most of these studies have focused on urban populations that experience lower incidence rates of HAV infection. In the current study, the prevalence of anti-HAV antibodies was investigated in children with a low socioeconomic status (SES) that live on the periphery of three capital cities in Brazil. A total of 1,162 dried blood spot samples were collected from individuals whose ages ranged from one-18 years and tested for anti-HAV antibodies. A large number of children under five years old (74.1-90\%) were identified to be susceptible to HAV infection. The anti-HAV antibody prevalence reached $\geq 50 \%$ among those that were 10-14 years of age or older. The anti-HAV prevalence rates observed were characteristics of regions with intermediate level of hepatitis A endemicity. These data indicated that a large proportion of children with a low SES that live at the periphery of urban cities might be at risk of contracting an HAV infection. The hepatitis A vaccine that is currently offered in Brazil is only available for high-risk groups or at private clinics and is unaffordable for individuals with a lower SES. The results from this study suggest that the hepatitis A vaccine should be included in the Brazilian National Program for Immunisation.

Key words: hepatitis A - epidemiology - Brazil - prevalence - hepatitis A vaccines

Infection with hepatitis A virus (HAV) is the most common cause of acute viral hepatitis worldwide (Jacobsen \& Wiersma 2010). The incidence of HAV infection and the prevalence of antibodies against HAV are closely associated with economic development and access to safe drinking water and sanitation. As individual income increases and access to safe drinking water and improved sanitation conditions increases, the incidence of HAV infection decreases (Jacobsen \& Wiersma 2010). The highest incidence rates of HAV infection have previously been reported to occur in the developing countries of Africa, Central and South America and southeast Asia (David 2004). In these countries, more than $90 \%$ of the population has acquired a natural immunity to HAV prior to 10 years of age. Because the asympto-

Financial support: FINEP, CNPq

+ Corresponding author: clvitral@ioc.fiocruz.br

Received 18 October 2011

Accepted 15 February 2012 matic form of infection is the most common in children, outbreaks of HAV are uncommon. However, over the last decade, several of these developing countries have undergone a change in the endemicity of HAV infection due to an improved standard of living. For example, in South America, recent studies have observed a progressive decrease in HAV seroprevalence rates (Tapia-Conyer et al. 1999, Clemens et al. 2000, Tanaka 2000, Vitral et al. 2006, 2008, Jacobsen \& Wiersma 2010). This transition of the HAV epidemiological pattern from a high to a medium endemicity is worrisome, as the delay in the age of exposure does not eliminate the risk of infection later in life. From a public health perspective, it is important to identify such epidemiological shifts because the severity of HAV disease increases with age, thus leading to an increased disease burden in older population groups.

Brazil is a developing country that has problems with sanitary conditions in many parts of the country. However, Brazil has experienced a significant economic growth recently. This economic development has led to improvements in sanitation and better living conditions for a large proportion of Brazilian citizens. In addition to these improvements, both a decrease in 
the circulation of HAV (Clemens et al. 2000, Vitral et al. 2006, 2008, Jacobsen \& Wiersma 2010) and a progressive decline in the number of fatal HAV infections have been observed in all regions of Brazil (Vitral et al. 2006). However, the HAV seroprevalence studies that have been performed have focused on the urban populations of Brazil that experience lower incidence rates than the rural populations (Ferreira et al. 1996, Vitral et al. 1998a, b, Clemens et al. 2000, Zago-Gomes et al. 2005, Dinelle et al. 2006, Fiaccadori et al. 2006, de Alencar Ximenes et al. 2008, Krebs et al. 2011). Having an accurate understanding of the epidemiology of HAV infection is important for understanding its effect on population groups that have not benefited from the recent improvements in sanitation conditions in Brazil. The current study attempted to collect epidemiological data about HAV seroprevalence in children and adolescents with a low socioeconomic status (SES) and who live at the periphery of three capital cities in different regions of Brazil. These data will allow a better understanding of the importance of implementing preventive hepatitis A vaccination programs in the country.

\section{SUBJECTS, MATERIALS AND METHODS}

Study design and subjects - This cross-sectional, seroprevalence study of HAV infection was conducted between April 2007-July 2009. A total of 1,162 children and adolescents that ranged in age from one-18 years, that had a low SES and that lived on the outskirts of Rio de Janeiro, Cuiabá and Manaus were enrolled in the study. These cities are the capitals of the states of Rio de Janeiro (RJ), Mato Grosso and Amazonas (AM), respectively, and are located in the Southeast (SE), Midwest (MW) and North (NO) Regions of Brazil, respectively (Fig. 1).

In the SE Region, the study participants were residents from the Complexo de Manguinhos, which is located in the northern area of the city of Rio de Janeiro and has an estimated population of 26,834 inhabitants in 13 total communities. The Complexo de Manguinhos has benefited from recent improvements through governmental programs (PAC-Portal Brasil 2010). Enrolment of the study participants was performed in April 2008 at the Health Unit and School Germano Sinval Faria/National School of Public Health/Oswaldo Cruz Foundation (Fiocruz)/Health Ministry. This school was founded in 1967 to serve residents from the Complexo de Manguinhos. All individuals between one-18 years of age or their guardians that attended the Health Unit during April 2008 were invited to participate in the study.

In the MW Region, the study participants consisted of residents from the districts of João Bosco Pinheiro and Dr Fabio, which are located on the periphery of Cuiabá. These communities have an estimated population of 10,000 individuals. Both districts were established after the invasion of public areas. All of the subjects from these districts are provided health care assistance through the Family Program of the Federal University of Mato Grosso (UFMT). A total of 322 subjects from the 122-catalogued families were randomly selected. A group of health care providers visited each house be- tween February 2008-July 2009 to invite children or their guardians to participate in the study.

The population that was selected in the NO Region was a rural community called the Assentamento Rural de Rio Pardo. This community is located in a geographical area belonging to the municipality of Presidente Figueiredo that is located in AM and is $140 \mathrm{~km}$ from Manaus. Approximately 600 inhabitants live in the community which was established between an area of rural settlement and an area of ecological preservation. Agriculture, fishing, hunting and stock farming provide food for the population. The community does not have proper sanitation facilities and most of the families have a low monthly income (less than 1 minimum salary, equivalent to $<$ US $\$ 175 /$ month). The invitation to participate in this study was performed at the community schools during April 2007 and all children between one-18 years of age were included in the study.

Data collection - The criteria for inclusion in the study were the following: individuals were between one-18 years of age and a resident of one of the regions described above. All participants or guardians were interviewed by trained health care personnel using a structured questionnaire. Sociodemographic data, which are thought to have a negative or positive influence on anti-HAV seropositivity, were collected. The SES of the participants was determined by both family income and the SES index adapted from Toukan et al. (1990). The SES index score

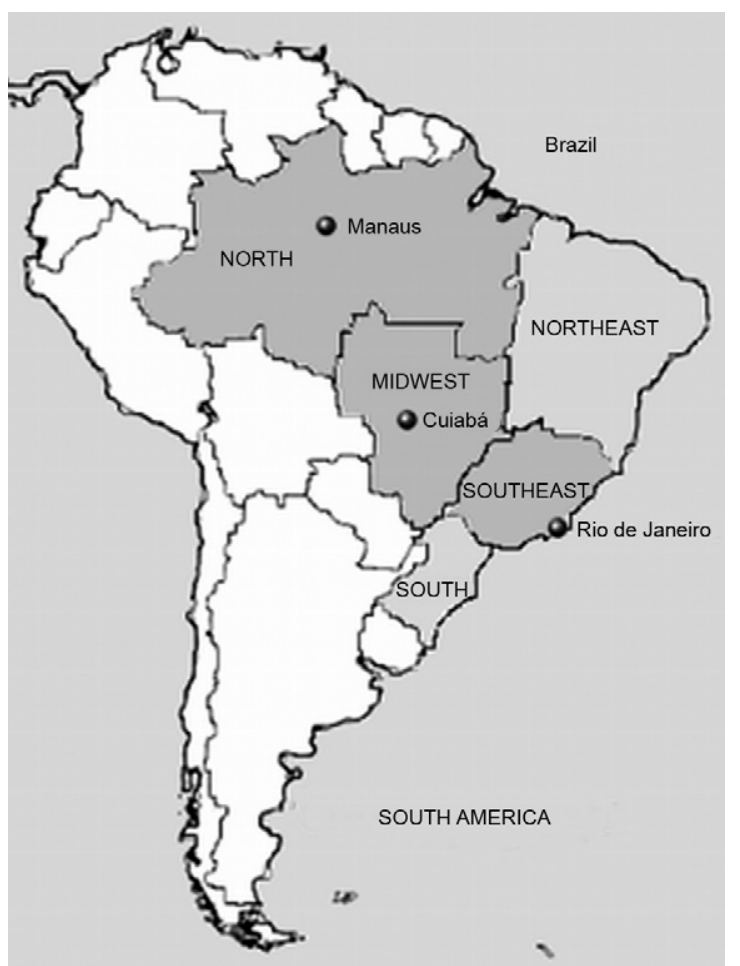

Fig. 1: map illustrating the five geographical Regions of the Brazil territory, showing the localization of the three regions and capitals cities enrolled in the study. 
of each participant was evaluated to be between $0-38$, representing the following: 0-18 very low, 19-23 low, 2428 medium and 29-38 high. In the NO Region, the data available for the study participants included age, gender and village of residence. The study participants were categorised into the following four age groups: one-four years, five-nine years, 10-14 years and 15-18 years.

Ethics - The study was conducted to conform to the provisions of the Declaration of Helsinki. Protocols for the collection and use of human samples were submitted and approved by the Human Research Committees of Fiocruz/RJ (protocol 442/07) and UFMT (protocol $351 / 07$ ). Prior to conducting the study, written informed consent was obtained from all subjects or, in the case of minors, from their parents or legal guardians.

Laboratory assays - A dried blood spot (DBS) sample was obtained from each subject that was enrolled in the study. The sample was processed and assayed for total antibodies against HAV (anti-HAV) using a commercial enzyme immunoassay (Bioelisa HAV, Biokit, Spain) according to previously described protocols (Melgaço et al. 2011).

Determination of sample size - Sample size calculations were based on a $30 \%$ estimated HAV seroprevalence, a $5 \%$ precision rate and a $95 \%$ confidence level. The formula for sample size determination (OpenEpi Epidemiologic Calculator 2006) indicated a total of 314 and 304 children for the SE and MW Regions, respectively. In the NO Region, all of the 154 individuals from the community of Rio Pardo whose ages ranged from one-18 years were included in the study.

Statistical analysis - Multiple logistic regressions was used to determine independent effects on the association between the presence of anti-HAV IgG and explanatory variables and to estimate the adjusted odds ratio $(\mathrm{OR})$ and confidence intervals (CI) (95\%) through selection of the better Akaike information criterion (AIC). In the initial logistic model, all variables associated with seropositivity in univariate analyses were included with $p<0.05$. Variables showing statistically significant associations with anti-HAV IgG positivity were kept in the final model. Analyses were performed using SPSS software version 17.0 for Windows (SPSS Inc, Chicago, USA, 2009).

\section{RESULTS}

A total of 1,162 children and adolescents were enrolled in the current study. Of the study participants, 686 were from the SE Region, 322 were from the MW Region and 154 were from the NO Region. The means \pm standard deviation age of the participants were $7.7 \pm 4.3,9.3 \pm 4.2$ and $8.1 \pm 3.5$ for the SE, MW and NO groups, respectively. The high number of participants that were enrolled from the SE Region was a result of the acceptance of all volunteers as study participants from this region.

SE Region - Among the 686 participants from the SE Region, 353 were female (51.5\%). Most of the participants lived in reinforced concrete houses $(643 / 680,94.6 \%)$ that had access to piped water $(671 / 680,98.7 \%)$ and a functioning sewer system $(645 / 679,95 \%)$. Based on family in- come, the majority of the participants had low SES $(81.9 \%$ received 2 or less monthly minimum wages - US\$375 or less). The resulting SES score was based on the sum of the available household items. Most of the children had mothers $(451 / 667,67.6 \%)$ and fathers $(452 / 620,72.9 \%)$ with nine years or less of education, corresponding to either a primary or secondary school level of education.

The overall prevalence of anti-HAV antibodies was $40.4 \%$ (277/686) and prevalence was significantly correlated with age $(\mathrm{p}<0.0001)$ (Table I). HAV seroprevalence was also significantly associated with other variables, including the study participant's race, the educational level of the study participant's father and mother, the family's income, the number of siblings, the use of filtered water, the number of family members, the habitation in reinforced concrete houses and the SES index (Table I). The results of the logistic regression analysis are shown in Table II. The following factors increased the risk of scoring positive for anti-HAV antibodies: elevated age, race and presence of more than two siblings in the household. The use of filtered water and living in a reinforced concrete house were considered to be protective factors against contracting HAV.

MW Region - Among the 322 participants from the MW Region, 175 (54.3\%) were female. Most of the participants lived in reinforced concrete houses $(98.8 \%)$ that had an artesian well as the water supply system $(92.8 \%)$. The district did not have a sewer system, but each household had a cesspool that was used to dispose of sewage. The monthly family income of approximately half of the participants $(45.9 \%)$ was one or less minimum monthly wages (US\$188 or less) and it was between two-four minimum monthly wages (375-US\$750) for the remaining $54.1 \%$ of the participants. The SES index indicated that $48.3 \%$ and $39.3 \%$ of the participants had a very low and a low SES, respectively.

The overall prevalence of anti-HAV antibodies was $39.8 \%(128 / 322)$ and was significantly correlated with age $(\mathrm{p}<0.0001)$ (Table III). Only $13.2 \%$ of the children that were one-four years of age were seropositive for anti-HAV antibodies. In groups beyond this age group, the prevalence of anti-HAV antibodies increased (Fig. 1). In the univariate analysis, the presence of anti-HAV antibodies was significantly associated with the following: the female gender (46.9\% vs. $31.3 \%$, OR $=1.9$, CI $95 \%: 1.2-3.2, p=0.006)$, the number of siblings in the household $(p<0.0001)$ and a previous history of hepatitis $(p=0.01)$. Multivariate analyses confirmed the association of age with HAV seropositivity. A median SES was considered a protective factor for HAV seropositivity. Although the female gender tended to have an increased chance of being seropositive, this association was not significant (OR 0.4, CI 95\% 0.9-3.3).

NO Region - Among the 155 study participants from the NO Region, 64 (41.5\%) were female. The overall prevalence of anti-HAV antibodies was $49 \%(76 / 155)$. The anti-HAV antibody prevalence rate according to age was as follows: $25.9 \%$ prevalence in the group from one-four years of age, $39.5 \%$ prevalence in the group from five-nine years of age, $74.5 \%$ in the group from $10-15$ years of age and $80 \%$ in the group from $15-18$ years of age (Fig. 2). 
Analysis of the age-associated prevalence of antiHAV antibodies in the three studied Regions - Fig. 2 indicates the overall results of the HAV seroprevalence rates according to age group in the three studied population groups. In all three of the Regions of Brazil, a large number of children from one-four years of age (74.190\%) were susceptible to a HAV infection. The overall prevalence of anti-HAV antibodies in this age group was only $12.1 \%$ (varied from $10-25.9 \%$ ). Among those participants from one-18 years of age, the prevalence was $41.9 \%$ (varied from $39.8-49 \%$ ), which characterised the overall population group that was evaluated as having an intermediate level of hepatitis A endemicity.

\section{DISCUSSION}

The results from this study indicated that only $10 \%$, $13.2 \%$ and $25.9 \%$ of children under the age of five from the SE, MW and NO Regions of Brazil, respectively, were HAV seropositive. The anti-HAV antibody prevalence was $\geq 50 \%$ only among individuals that were 15 years old or older, indicating that these population groups had an intermediate level of endemicity for HAV (Jacob-

\section{TABLE I}

Prevalence of total anti-hepatitis A virus (HAV) and distribution of associated risk factors among children and adolescents living in the periphery of the municipality of Rio de Janeiro, southeastern Brazil

\begin{tabular}{|c|c|c|c|c|c|}
\hline Variable $^{a}$ & $\begin{array}{c}\text { Anti-HAV+ } \\
\text { n }(\%)\end{array}$ & $\begin{array}{c}\text { Anti-HAV- } \\
\text { n }(\%)\end{array}$ & $\mathrm{p}$ & $\mathrm{OR}^{d}$ & $95 \% \mathrm{CI}$ \\
\hline Age group (years) & & & $<0.0001$ & & \\
\hline $1-4$ & $18(10)$ & $162(90)$ & - & 1.00 & - \\
\hline $5-9$ & $134(46.7)$ & $153(53.3)$ & - & 7.88 & $(4.47-14.05)$ \\
\hline $10-14$ & $94(57)$ & $71(43)$ & - & 11.92 & $(6.47-22.15)$ \\
\hline $15-18$ & $31(57.4)$ & $23(42.6)$ & - & 12.13 & $(5.53-26.90)$ \\
\hline Skin colour & & & $<0.0001$ & & \\
\hline White & $57(24.8)$ & $172(75.1)$ & - & 1.00 & - \\
\hline Mulatto & $83(42.5)$ & $112(57.4)$ & - & 2.24 & $(1.45-3.45)$ \\
\hline Negro & $125(56.3)$ & $97(43.6)$ & - & 3.89 & $(2.56-5.92)$ \\
\hline Fathers' level of education ${ }^{b}$ (years) & & & $<0.0001$ & & \\
\hline$\leq 9$ years & $207(45.8)$ & $245(54.2)$ & - & 2.53 & $(1.68-3.84)$ \\
\hline$>9$ years & $42(25)$ & $126(75)$ & - & 1.00 & - \\
\hline Mother'level of education ${ }^{b}$ (years) & & & $<0.0001$ & & \\
\hline$\leq 9$ years & $216(47.9)$ & $235(52.1)$ & - & 2.79 & $(1.92-4.07)$ \\
\hline$>9$ years & $53(24.7)$ & $161(75.2)$ & - & 1.00 & - \\
\hline Family income ${ }^{c}$ & & & $<0.0001$ & & \\
\hline$\leq 1$ & $132(50.8)$ & $128(49.2)$ & - & 1.00 & - \\
\hline $1-2$ & $106(38)$ & $173(62)$ & - & 0.59 & $(0.42-0.85)$ \\
\hline$>2-3$ & $21(26.3)$ & $59(73.8)$ & - & 0.35 & $(0.19-0.62)$ \\
\hline$>3$ & $9(23)$ & $30(76.9)$ & - & 0.29 & $(0.12-0.67)$ \\
\hline Persons/household (n) & & & 0.0006 & & \\
\hline$\leq 5$ & $198(37.2)$ & $333(57.3)$ & - & 1.00 & - \\
\hline$>5$ & $79(53.4)$ & $69(57.4)$ & - & 1.93 & $(1.31-2.83)$ \\
\hline Siblings (n) & & & $<0.0001$ & & \\
\hline$\leq 2$ & $134(31.3)$ & $294(68.6)$ & - & 1.00 & - \\
\hline$>2$ & $142(56.8)$ & $108(43.2)$ & - & 2.88 & $(2.06-4.04)$ \\
\hline Use of filtered water & & & $<0.0001$ & & \\
\hline No & $125(58.4)$ & 89 (41.6) & - & 2.89 & $(2.03-4.10)$ \\
\hline Yes & $147(32.7)$ & $302(67.3)$ & - & 1.00 & - \\
\hline Reinforced concrete house & & & 0.0010 & & \\
\hline No & $25(67.6)$ & $12(32.4)$ & - & 3.25 & $(1.53-7.00)$ \\
\hline Yes & $251(39)$ & $392(61)$ & - & 1.00 & - \\
\hline SES index & & & 0.01 & & \\
\hline Very low or low & $162(45.1)$ & $197(54.8)$ & - & 1.50 & $(1.09-2.07)$ \\
\hline Middle or high & $114(35.4)$ & $208(64.5)$ & - & 1.00 & - \\
\hline
\end{tabular}

$a$ : totals do not add up to 686 because of missing values; $b$ : $\leq$ nine years, primary or middle school or $>$ nine years, high school or university; $c$ : number of minimum wages (US\$ 375 each) received per month; $d$ : odds ratio (OR) $1.00=$ referent; CI: confidence interval. 
sen \& Wiersma 2010). The rates of anti-HAV antibody prevalence that were observed in the current study were below the rates that have been reported for low SES population groups (Pannuti et al. 1985, Abuzwaida et al. 1987, Bensabath et al. 1987, Queiroz et al. 1995, Ferrreira et al. 1996, Assis et al. 2002, Almeida et al. 2006). Instead, the prevalence rates reported here were similar to those that have been reported for groups that live in urban areas of Brazil and that have higher monthly incomes (Ferreira et al. 1996, Zago-Gomes et al. 2005, Dinelli et al. 2006, Krebs et al. 2011). Our results were also in agreement with the prevalence rates that have been described in the population-based survey that was conducted in the urban areas of the capital cities of Brazil (de Alencar Ximenes et al. 2008). These data suggest that a decrease in the infection rate of HAV may be occurring even among the lower socioeconomic groups in Brazil.

In the present study, most of the participants had a low SES as classified by low family income and the SES index. However, the participants lived in communities that had differing sanitation facilities. The community on the periphery of Rio de Janeiro in the SE Region continues to receive assistance to increase the general standard of living. The impact of these improvements on the prevalence of anti-HAV antibodies is apparent when our data are compared with data that were obtained in a previous study

\section{TABLE II}

Multivariate analysis of anti-hepatitis A virus (HAV) risk factors among children and adolescents of the municipality of Rio de Janeiro, southeastern Brazil

\begin{tabular}{|c|c|c|c|}
\hline Variable & $\mathrm{OR}^{a}$ & $95 \%$ CI & $\mathrm{p}$ \\
\hline \multicolumn{4}{|c|}{ Age group (years) } \\
\hline $1-4$ & 1.00 & - & - \\
\hline $5-9$ & 9.01 & $(4.83-16.78)$ & $<0.0001$ \\
\hline $10-14$ & 16.18 & $(8.26-31.66)$ & $<0.0001$ \\
\hline $15-19$ & 10.88 & $(4.63-25.86)$ & $<0.0001$ \\
\hline \multicolumn{4}{|c|}{ Skin colour } \\
\hline White & 1.00 & - & - \\
\hline Mulatto & 2.55 & $(1.59-4.11)$ & 0.0001 \\
\hline Negro & 1.77 & $(1.08-2.88)$ & 0.0225 \\
\hline \multicolumn{4}{|c|}{ Family income ${ }^{b}$} \\
\hline$\leq 1$ & 1.00 & - & - \\
\hline $1-2$ & 0.65 & $(0.42-1.00)$ & 0.0511 \\
\hline$>2-3$ & 0.44 & $(0.23-0.84)$ & 0.133 \\
\hline$>3$ & 0.47 & $(0.19-1.18)$ & 0.0108 \\
\hline \multicolumn{4}{|c|}{ Used of filtered water } \\
\hline No & 1.00 & - & - \\
\hline Yes & 0.52 & $(0.34-0.80)$ & 0.0025 \\
\hline \multicolumn{4}{|c|}{ Reinforced concrete house } \\
\hline No & 1.00 & - & - \\
\hline Yes & 0.29 & $(0.11-0.76)$ & 0.0118 \\
\hline \multicolumn{4}{|c|}{ Siblings (n) } \\
\hline$\leq 2$ & 1.00 & - & - \\
\hline$>2$ & 1.48 & $(1.25-1.75)$ & $<0.0001$ \\
\hline
\end{tabular}

$a$ : odds ratio(OR) $1.00=$ referent; $b$ : number of minimum wages (US\$ 375 each) received per month; CI: confidence interval. performed using participants from the same community in 2002 (dos Santos et al. 2002). Our study showed a significant decrease in HAV seroprevalence among children aged one-18 years old, indicating that the rates decreased from $70-40.4 \%$ in the span of nine years $(p<0.0001)$.

The community that was studied in the MW Region did not have piped water or a public sewer system, but all residents had their own artesian well for water and a septic cesspool for disposal of sewage. Despite the more simplistic mechanisms of water and sewage disposal, these facilities seemed to be efficient as indicated by the low anti-HAV antibody prevalence among the youngest age groups in these communities.

The relatively low prevalence of anti-HAV antibodies in children one-four years old (13.2\%) and five-nine years old $(28.3 \%)$ in a very low income community located in the Brazilian Amazon was surprising. This region is known to be highly endemic for HAV with seroprevalence rates as high as $90 \%$ among children that are 10 years old or younger (Bensabath et al. 1987, de Paula et al. 2001, Assis et al. 2002). Our results are in agreement with results from Braga et al. (2009), who demonstrated an intermediate pattern of HAV infection in isolated communities in the western Brazilian Amazon region. This unexpected intermediate pattern of HAV infection could be explained by the isolation of these small villages, resulting in a decreased contact with the outside world in childhood. In such isolated communities, it can also be assumed that HAV is not circulating extensively.

\section{TABLE III}

Multivariate analysis of anti-hepatitis A virus (HAV) risk factors among children and adolescents living in the periphery of the municipality of Cuiabá, Midwest Region of Brazil

\begin{tabular}{|c|c|c|c|c|}
\hline Variable & $\begin{array}{c}\text { Crude } \mathrm{OR}^{a} \\
\text { (p) }\end{array}$ & $\begin{array}{c}\text { Adjusted } \\
\mathrm{OR}^{a}\end{array}$ & $95 \% \mathrm{CI}$ & $\mathrm{p}$ \\
\hline \multicolumn{5}{|l|}{ Gender } \\
\hline Male & 1.0 & 1.0 & - & - \\
\hline Female & 1.9 & 1.7 & $0.9-3.3$ & 0.000 \\
\hline \multicolumn{5}{|c|}{ Age groups (years) } \\
\hline $1-4$ & 1.0 & 1.0 & - & - \\
\hline $5-9$ & 2.6 & 2.3 & $0.9-5.8$ & 0.066 \\
\hline $10-14$ & 7.7 & 6.4 & $2.5-16.3$ & 0.000 \\
\hline $15-18$ & 14.5 & 14.0 & $4.8-40.5$ & 0.000 \\
\hline \multicolumn{5}{|l|}{ SES index } \\
\hline Very low & 1.0 & 1.0 & - & - \\
\hline Low & 1.0 & 0.9 & $0.5-1.7$ & 0.993 \\
\hline Middle & 0.5 & 0.4 & $0.1-0.9$ & 0.038 \\
\hline \multicolumn{5}{|l|}{ Siblings (n) } \\
\hline 0 & 1.0 & 1.0 & - & - \\
\hline 1 & 1.9 & 1.8 & $0.6-5.0$ & 0.245 \\
\hline 2 & 2.8 & 1.9 & $0.7-5.3$ & 0.196 \\
\hline $3-9$ & 4.3 & 2.6 & $0.9-7.5$ & 0.060 \\
\hline
\end{tabular}

$a$ : odds ratio $(\mathrm{OR}) 1.00=$ referent; $\mathrm{CI}$ : confidence interval; SES: socioeconomic status. 
An increase in age, race and the number of siblings living with the study participant were associated with an increased chance of being anti-HAV seropositive. The use of filtered water, living in a reinforced concrete house and having an intermediate SES were considered protective factors for HAV seropositivity. In agreement with several HAV epidemiological studies (Vitral et al. 1998a, ZagoGomes et al. 2005, Almeida et al. 2006), age was the variable that was most strongly associated with the prevalence of anti-HAV antibodies in all population groups. These data suggest that the HAV infection risk is determined more by the increased exposure time of older individuals than to the environment in which HAV circulates.

Refusal to participate in this study, even among the youngest age groups, was minimal (less than 5\%). All blood samples were obtained by pricking the finger and depositing a blood spot on filter paper (DBS), a process that represents an easy and inexpensive method to collect, transport and store samples. This method has previously been observed to have a sensitivity and specificity of $100 \%$ when compared with collection of plasma for the detection of anti-HAV antibodies after infection (Melgaço et al. 2011). Seroepidemiological surveys to detect the presence of antibodies are typically performed by collecting venous blood by venipuncture. However, the invasive nature of such a method of blood collection could reduce the potential value of these studies, mainly among populations of infants and young children. According to Neto et al. (1995), refusal to enrol in clinical studies that require venipuncture can be approximately 13\%. de Alencar Ximenes et al. (2008) indicated that children aged zero-four years old were excluded from a population-based study that was conducted in Brazil to minimise the refusal rate for participation in the study.

In conclusion, the low anti-HAV antibody prevalence rate that was observed in children and adolescents reflects a decreasing exposure to HAV infection even among individuals in lower socioeconomic groups who live on the periphery of Brazilian capital cities. The reduced exposure to HAV was associated with an increased standard of living and a decreased circulation of HAV. Although improvements in sanitary facilities represent a crucial method to reduce the transmission of infectious diseases, the control of HAV cannot wait until the conclusion of the Brazilian Program of Basic Sanitation, which could require many decades until

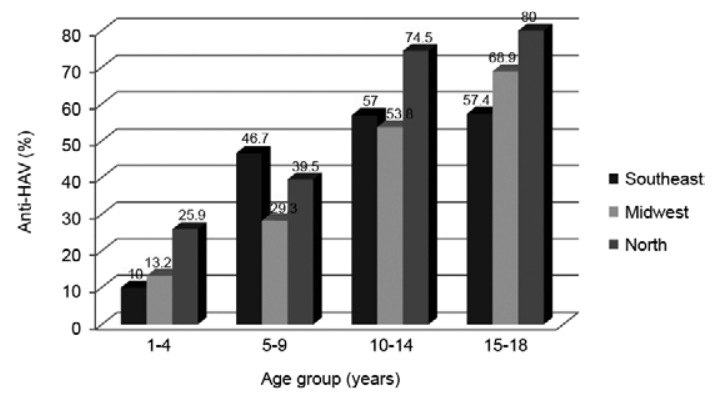

Fig. 2: global analysis of age distribution of anti-hepatitis A virus (HAV) seropositivity according to Brazilian Regions. completion. However, the incidence of HAV infection could be reduced up to $95 \%$ with the implementation of a nationwide HAV vaccination program, as reported in Israel (Dagan et al. 2005), USA (Wasley et al. 2005) and Argentina (Vacchino 2008). Additionally, an increased standard of living without proper immunisation can result in an increasing population of susceptible individuals that are at risk of contracting an HAV infection. In areas of high HAV endemicity, most children become infected before the age of 10 , usually without any clinical symptoms. Because the chance of developing symptomatic HAV infection increases with age, as a country or a sub-population of individuals experiences a transition to a lower endemicity for HAV, those who do become infected are at an increased risk of having a symptomatic HAV infection, which includes acute liver failure and death (Ciocca 2000). Thus, a decrease in the $\mathrm{HAV}$ incidence rate in the population often results in an increase in the health care costs per case of HAV infection and a subsequent increase in total HAV-associated public health care costs (Luyten \& Beutels 2009).

The hepatitis A vaccine is still not included in the Brazilian National Program for Immunisation. It is currently only offered at Reference Centres for Special Immunobiologicals for some population groups that are at high risk for HAV infection or at private immunisation clinics. Currently, the administration of the vaccine has been restricted to individuals with a higher SES because of the high cost of the vaccine. Children with a lower SES susceptible to HAV infection will need to depend on governmental programs to protect them from HAV. The results from our study suggest that the hepatitis A vaccine should be included in the Brazilian Ministry of Health Immunisation Schedule. The introduction of HAV immunisation before admittance to school could be an important strategy for the control of HAV infections in Brazil.

\section{REFERENCES}

Abuzwaida ARN, Sidoni M, Yoshida CFT, Schatzmayr HG 1987. Seroepidemiology of hepatitis A and B in two urban communities of Rio de Janeiro, Brazil. Rev Inst Med Trop S Paulo 29: 219-223.

Almeida D, Tavares-Neto J, Vitvitski L, Almeida A, Mello C, Santana D, Tatsch F, Paraná R 2006. Serological markers of hepatitis A, $\mathrm{B}$ and $\mathrm{C}$ viruses in rural communities of the semiarid Brazilian Northeast. Braz J Infect Dis 10: 317-321.

Assis SB, Souto FJD, Fontes CJF, Gaspar AMC 2002. Prevalência da infecção pelos vírus das hepatites A e E em escolares de um município da Amazônia Matogrossense, Brasil. Rev Soc Bras Med Trop 35: 155-158.

Bensabath G, Hadler SC, Soares MCP, Fields H, Maynard JE 1987. Caracteristicas sorologicas y epidemiologicas de la hepatitis virica aguda en la Cuenca. Bol Of Sanit Panam 103: 351-362.

Braga WSM, Borges FG, Júnior GMB, Martinho ACS, Rodrigues IS, de Azevedo EP, Davis GHNG, de Queiroz MB, dos Santos SHD, Barbosa TV, Castilho MC 2009. Prevalence of hepatitis A virus infection: the paradoxical example of isolated communities in the western Brazilian Amazon region. Rev Soc Bras Med Trop 42: 211-281.

Ciocca M 2000. Clinical course and consequences of hepatitis A infection. Vaccine 18 (Suppl.): S71-S74.

Clemens SA, da Fonseca JC, Azevedo T, Cavalcanti A, Silveira TR, Castilho MC, Clemens R 2000. Hepatitis A and hepatitis B seroprevalence in 4 centers in Brazil. Rev Soc Bras Med Trop 33: 1-10. 
Dagan R, Leventhal A, Anis E, Slater P, Ashur Y, Shouval D 2005. Incidence of hepatitis A in Israel after universal immunization of toddlers. JAMA 294: 202-210.

David AM 2004. Hepatitis A outbreaks-methods of intervention in south-east Asian countries. Int J Infect Dis 8: 201-209.

de Alencar Ximenes RA, Martelli CM, Merchán-Hamann E, Montarroyos UR, Braga MC, de Lima ML, Cardoso MR, Turchi MD, Costa MA, de Alencar LC, Moreira RC, Figueiredo GM, Pereira LM 2008. Multilevel analysis of hepatitis A infection in children and adolescents: a household survey in the Northeast and CentralWest Regions of Brazil. Int J Epidemiol 37: 852-861.

de Paula VS, Arruda ME, Vitral CL, Gaspar AMC 2001. Seroprevalence of viral hepatitis in riverine communities from the western region of the Brazilian Amazon Basin. Mem Inst Oswaldo Cruz 96: $1123-1128$

Dinelli MIS, Fisberg M, Moraes-Pinto MI 2006. Anti-hepatitis A virus frequency in adolescents at an outpatient clinic in São Paulo, Brazil. Rev Inst Med Trop S Paulo 48: 43-44.

Ferreira CT, Silva GL, Fereira-Lima J, Barros FC 1996. Hepatitis A antibodies in two socioeconomically distinct populations of Porto Alegre, southern Brazil. J Trop Pediatr 44: 184-185.

Fiaccadori FS, Soares CM de A, Borges AMT, Cardoso DDP 2006. Prevalence of hepatitis A virus infection in Goiânia, Goiás, Brazil, by molecular and serological procedures, 1995-2002. Mem Inst Oswaldo Cruz 101: 423-426.

Jacobsen KH, Wiersma ST 2010. Hepatitis A virus seroprevalence by age and world region, 1990 and 2005. Vaccine 41: 6653-6657.

Krebs LS, Ranieri TM, Kieling CO, Ferreira CT, da Silveira TR 2011. Shifting susceptibility to hepatitis A among children and adolescents over the past decade. J Pediatr 87: 213-218.

Luyten J, Beutels P 2009. Costing infectious disease outbreaks for economic evaluation: a review for hepatitis A. Pharmacoeconomics 27: 379-389.

Melgaço JG, Pinto MA, Rocha AM, Freire M, Gaspar LP, Lima SMB, Cruz OG, Vitral CL 2011. The use of dried blood spots for assessing antibody response to hepatitis A virus after natural infection and vaccination. J Med Virol 83: 208-217.

Neto RSA, Richards A, Nokes DJ, Silveira ASB, Cohen BJ, Passos SD, Pannuti S, Massad E 1995. Salivary antibody detection in epidemiological surveys: a pilot study after a mass vaccination campaign against rubella in São Paulo, Brazil. Trans $R$ Soc Trop Med Hyg 89: 115-118.

OpenEpi Epidemiologic Calculator 2006. [database on the internet]. Open Source Epidemiologic Statistics for Public Health. [cited 17 Oct 2011]. Available from: openepi.com.

PAC-Portal Brasil 2010. [database on the internet]. Programa de Aceleração do Crescimento. [cited 17 Oct 2011]. Available from: brasil.gov.br/pac.
Pannuti CS, Mendonça JS, Carvalho MJM, Oselka GW, Amato NV 1985. Hepatitis A antibodies in two socioeconomically distinct populations of São Paulo, Brazil. Rev Inst Med Trop S Paulo 27: $162-164$.

Queiroz DA, Cardoso DD, Martelli CM, Martins RM, Porto SO, Borges AM, Azevedo MS, Daher RR 1995. Risk factors and prevalence of antibodies against hepatitis A virus (HAV) in children from day-care centers, in Goiânia, Brazil. Rev Inst Med Trop S Paulo 37: 427-433

dos Santos DCM, Souto FJD, dos Santos DRL, Vitral CL, Gaspar AMC 2002. Seroepidemiological markers of enterically transmitted viral hepatitis $\mathrm{A}$ and $\mathrm{E}$ in individuals living in a community located in the north area of Rio de Janeiro, RJ, Brazil. Mem Inst Oswaldo Cruz 97: 637-640.

Tanaka J 2000. Hepatitis A shifting epidemiology in Latin America. Vaccine 18 (Suppl.): S57-S60.

Tapia-Conyer R, Santos JI, Cavalcanti AM, Urdaneta E, Rivera L, Monterola A, Potin M, Ruttiman R, Kido JT 1999. Hepatitis A in Latin America: a changing epidemiologic pattern. Am J Trop Med Hyg 61: 825-829.

Toukan AU, Sharaiha ZK, Abu-el-Rub OA, Hmoud MK, Dahbour SS, Abu-Hassan H, Yacoub SM, Hadler SC, Margolis HS, Coleman PJ, Maynard JE 1990. The epidemiology of hepatitis B virus among family members in the Middle East. Am J Epidemiol 132: 220-232.

Vacchino MN 2008. Incidence of hepatitis A in Argentina after vaccination. J Viral Hepat 15: 47-50.

Vitral CL, Gaspar AMC, Souto FJD 2006. Epidemiological pattern and mortality rates for hepatitis A in Brazil 1980-2002 - A Review. Mem Inst Oswaldo Cruz 101: 119-127.

Vitral CL, Souto FJD, Gaspar AMC 2008. Changing epidemiology of hepatitis A in Brazil: reassessing immunization policy. $J$ Viral Hepat 15: 22-25.

Vitral CL, Yoshida CFT, Lemos ERS, Teixeira CS, Gaspar AMC 1998a. Age-specific prevalence of antibodies to hepatitis A in children and adolescents from Rio de Janeiro, Brazil, 1978 and 1995. Relationship of prevalence to environmental factors. Mem Inst Oswaldo Cruz 93: 1-5.

Vitral CL, Yoshida CFT, Teixeira CS, Gaspar AMC 1998b. Seroprevalence of hepatitis A in health care students from a public university of Rio de Janeiro, Brazil. Rev Microbiol 29: 149-151.

Wasley A, Samandari T, Bell B 2005. Incidence of hepatitis A in the United States in the era of vaccination. JAMA 294: 194-201.

Zago-Gomes MP, Stantolin GC, Perazzio S, Aikawa KH, Gonçalves CS, Pereira FE 2005. Prevalence of anti-hepatitis A antibodies in children of different socioeconomic conditions in Vila Velha, ES. Rev Soc Bras Med Trop 38: 285-289. 